MALARIA

JOURNAL

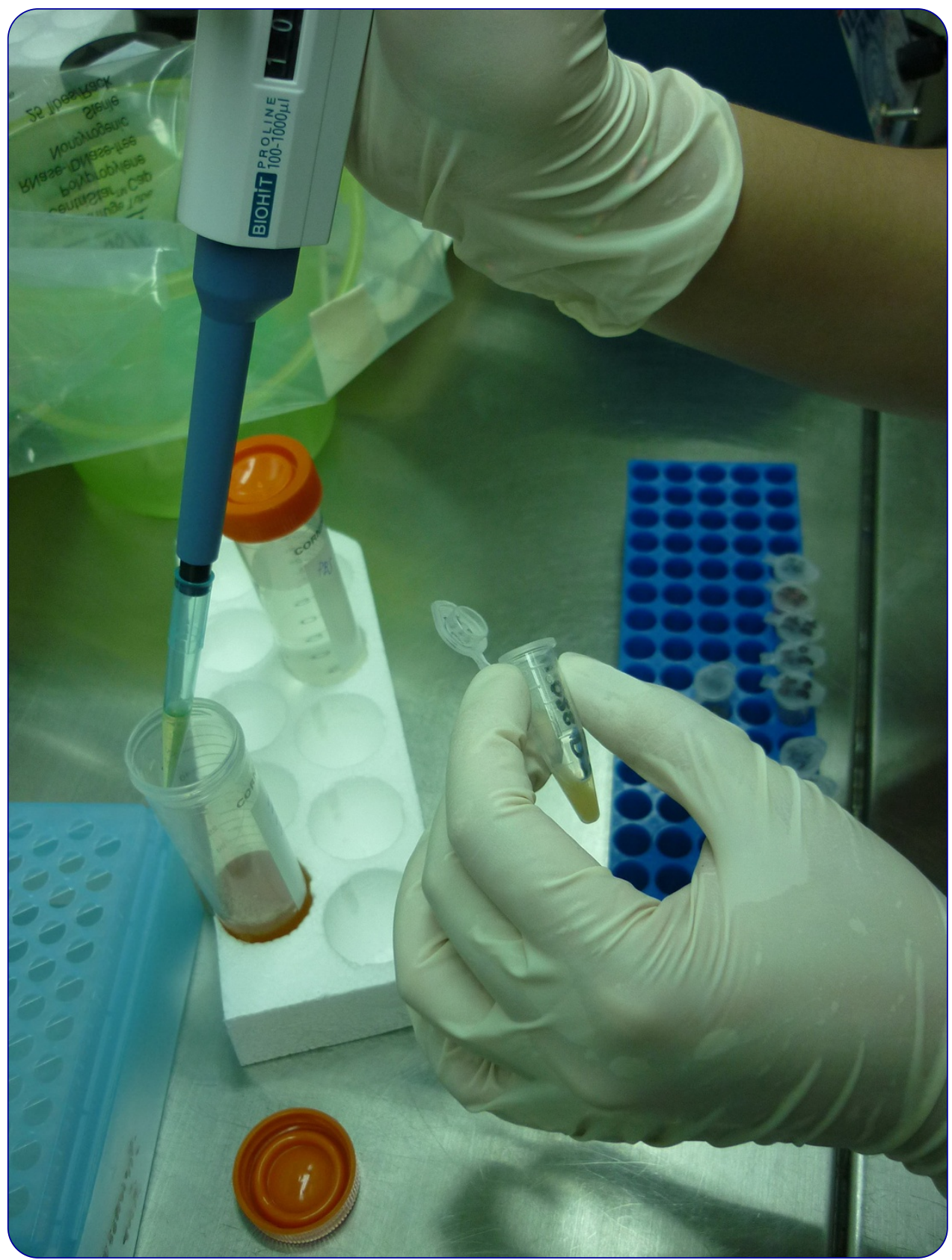

Nuclear factor kappa B in urine sediment: a useful indicator to detect acute kidney injury in Plasmodium falciparum malaria

Punsawad and Viriyavejakul 


\title{
Nuclear factor kappa B in urine sediment: a useful indicator to detect acute kidney injury in Plasmodium falciparum malaria
}

\author{
Chuchard Punsawad $^{1}$ and Parnpen Viriyavejakul ${ }^{2,3^{*}}$
}

\begin{abstract}
Background: Acute kidney injury (AKI) is one of the major complications of Plasmodium falciparum malaria, especially among non-immune adults. It has recently been revealed that activation of transcription factor nuclear factor kappa B (NF-kB) induces pro-inflammatory gene expression involved in the development of progressive renal inflammatory diseases. The aim of this study was to determine whether urinary sediment NF-KB p65 can act as a biomarker for AKI in patients with $P$. falciparum malaria.

Methods: Urinary sediments from malaria patients, including Plasmodium vivax malaria, uncomplicated $P$. falciparum malaria, complicated $P$. falciparum malaria without AKI (serum creatinine- $\mathrm{Cr}<3 \mathrm{mg} / \mathrm{dl}$ ) and complicated $P$. falciparum malaria with $\mathrm{AKI}(\mathrm{Cr} \geq 3 \mathrm{mg} / \mathrm{dl})$ were used to determine NF-KB p65 level by sandwich enzyme-linked immunosorbent assay (ELISA). Urinary sediments obtained from healthy controls were used as a normal baseline. Correlations between levels of urinary sediment NF-KB p65 and pertinent clinical data were analysed.

Results: Urinary sediment NF-KB p65 levels were significantly increased on the day of admission (day 0 ) and on day 7 post-treatment in complicated $P$. falciparum malaria patients with AKI, compared with those without AKI $(p=0.001$, $p<0.001$, respectively), $P$. vivax patients (all $p<0.001$ ) and healthy controls (all $p<0.001$ ). NF-KB p65 levels in urinary sediment cells showed a significant positive correlation with serum $\mathrm{Cr}$ (Day 0: $r_{s}=0.792 ; p<0.001$, Day 7: $r_{s}=0.605$; $p<0.001$ ) and blood urea nitrogen (BUN) (Day 0: $r_{s}=0.839 ; p<0.001$, Day 7: $r_{s}=0.596 ; p<0.001$ ).
\end{abstract}

Conclusions: Urinary sediment NF-KB p65 level is a useful indicator for estimating renal tubular epithelial cell damage and subsequent development of AKI among patients with P. falciparum malaria.

Keywords: Malaria, Plasmodium falciparum, Nuclear factor kappa B (NF-kB), Urinary sediment, Acute kidney injury (AKI)

\section{Background}

Acute kidney injury (AKI) is one of the serious complications of Plasmodium falciparum infection, with mortality rates as high as 70\% among untreated patients [1]. The rare incidence has also been reported in Plasmodium vivax, occasionally contributing to renal impairment [2]. Malarial AKI is more common among adults in tropical areas where transmission of malaria is low or unstable and where the disease occurs at all ages [3]. Clinical presentations of malarial AKI patients are usually oliguria with

\footnotetext{
* Correspondence: parnpen.vir@mahidol.ac.th

${ }^{2}$ Department of Tropical Pathology, Faculty of Tropical Medicine, Mahidol University, 420/6 Rajvithi Road, Bangkok, Thailand

${ }^{3}$ Center for Emerging and Neglected Infectious Diseases, Mahidol University, Bangkok, Thailand

Full list of author information is available at the end of the article
}

increasing levels of serum creatinine $(\mathrm{Cr})$, but urine output may also be normal [3]. Several factors have been implicated in the pathogenesis of malarial AKI, including the cyto-adherence of parasitized red blood cells (PRBCs), the effect of various chemical mediators, dehydration, intravascular haemolysis, and hyperparasitaemia [4]. Studies on Southeast Asian adults dying from severe falciparum malaria have indicated that the frequency of PRBC sequestration in the renal blood vessels of patients dying from AKI was significantly higher than those without AKI $[5,6]$.

AKI is generally characterized by the sudden loss of the kidneys' ability to concentrate urine, excrete waste, conserve electrolytes, and maintain fluid balance. The disease is associated with a mortality rate of between 50 
and $80 \%$ [7]. The loss of kidney function is usually detected by the measurement of serum $\mathrm{Cr}$ or by a rise in blood urea nitrogen (BUN). BUN is a non-specific indicator of renal function as urea production can be altered by dehydration, food intake and tissue catabolism [3]. Thus, serum $\mathrm{Cr}$ is more specific in assessing renal function than BUN [8]. In general, it has been approximated that the incidence of AKI in the intensive care unit was about $1-25 \%$ and the mortality rate was $15-60 \%$ [9]. In Thailand, the incidence of AKI in P. falciparum malaria varies from $0.14-0.18 \%$ at the Hospital for Tropical Diseases, Bangkok [10] and up to $73.9 \%$ at Mae Sot General Hospital using RIFLE criteria (risk, injury, failure, loss, and end-stage kidney disease) [11]. Existing kidney markers such as serum $\mathrm{Cr}$, urine output, and estimated glomerular filtration rate, become elevated only when a significant damage or loss of kidney function has occurred. Recently, urinary biomarkers such as interleukin-18 (IL-18), kidney injury molecule-1 (KIM-1) and neutrophil gelatinase-associated lipocalin (NGAL) have been reported as non-invasive and relatively inexpensive tools for assessing the degree and characteristics of inflammation and tubulo-interstitial damage [12,13]. Several studies have demonstrated that nuclear factor- $\mathrm{kB}(\mathrm{NF}-\mathrm{kB})$ is activated in the renal tubular epithelial cells, glomeruli and urothelial cells in renal injury $[14,15]$ and that renal inflammation can occur after induction by a variety of stimuli $[14,15]$. NF- $\mathrm{kB}$ is a family of dimeric transcription factors that regulates the expression of numerous genes involved in inflammation and cell proliferation [16]. The increased activation of NF-kB may indicate a response to renal tubular injury $[14,15]$.

This study investigated NF- $\mathrm{kB}$ p65 levels in urinary sediments from malaria patients to assess whether urinary sediments NF-kB p65 can serve as a sensitive tool for detecting $\mathrm{AKI}$ in $P$. falciparum malaria patients.

\section{Methods}

\section{Subjects}

Thirty-nine malaria patients admitted to the Hospital for Tropical Diseases, Faculty of Tropical Medicine, Mahidol University, Thailand were enrolled into this study. Classification of malaria species was based on microscopic identification. The patients were divided into four groups: 1) $P$. vivax malaria $(\mathrm{n}=11), 2)$ uncomplicated $P$. falciparum malaria $(\mathrm{n}=8), 3)$ complicated $P$. falciparum malaria without AKI $(\mathrm{Cr}<3 \mathrm{mg} / \mathrm{dl})(\mathrm{n}=10)$, and, 4) complicated P. falciparum malaria with AKI $(\mathrm{Cr} \geq 3 \mathrm{mg} / \mathrm{dl})(\mathrm{n}=10)$. Classification of complicated $P$. falciparum malaria was based on WHO criteria [3]. The control group consisted of 14 healthy volunteers living in Bangkok, a non-endemic malaria area. This group had no history of malaria infection. This study was approved by the Ethics Committee, Faculty of Tropical Medicine, Mahidol University (MUTM
2010-035-01, MUTM 2010-035-02). Written informed consent was obtained from all patients or their legal representatives before enrollment into the study.

\section{Blood and urine samples}

Five $\mathrm{ml}$ of whole blood were obtained from malaria patients on day 0 (pre-treatment) and day 7 (posttreatment). Samples of clotted blood were centrifuged at $1,700 \mathrm{~g}$ for $10 \mathrm{~min}$ and the serum was harvested and stored in an aliquoted state at $-70^{\circ} \mathrm{C}$. The serum was used to measure $\mathrm{Cr}$ and BUN levels to investigate kidney function. Urinary sediment NF- $\mathrm{kB}$ p 65 was determined by enzyme-linked immunosorbent assay (ELISA). Early morning whole-stream urine specimens were collected from all subjects on day 0 (pre-treatment) and day 7 (post-treatment). For urine sediment preparation, urine samples were centrifuged at 3,000 g for $15 \mathrm{~min}$ and urinary cell pellets were collected and stored at $-70^{\circ} \mathrm{C}$ until use. The proteins from urinary cell pellets were extracted by lysis buffer (Cell Signaling, MA, USA) containing protease inhibitors (Sigma-Aldrich, MO, USA) according to the manufacturers' protocol. In summary, the pellets were sonicated on ice, centrifuged at 14,000 g for $10 \mathrm{~min}$ at $4^{\circ} \mathrm{C}$ and the supernatants were harvested and used for ELISA. Protein concentrations were determined by Bradford assay (Pierce Biotechnology, IL, USA), using bovine serum albumin (BSA) as the standard. Fifteen $\mathrm{ml}$ of urine sample were sent to the laboratory immediately or stored at $4^{\circ} \mathrm{C}$ overnight for urine analysis.

\section{Measurement of urinary sediment NF-KB p65 levels}

The NF-kB p65 levels in urinary sediments were measured by sandwich ELISA kit (Cell Signaling, MA, USA) according to the manufacturer's protocol. Phospho-NF-kB p65 mouse monoclonal antibody diluted to 1: 100 in PBS was coated on a 96-well microplate and stored overnight. Protein samples $(45 \mu \mathrm{g} /$ well) were added and incubated for two hours at $37^{\circ} \mathrm{C}$. The plate was then washed with PBS containing $0.05 \%(\mathrm{w} / \mathrm{v})$ Tween-20 (PBS-T). Phospho-NF$\kappa \mathrm{B}$ p65 rabbit monoclonal antibody was added to the wells and incubated for one hour at $37^{\circ} \mathrm{C}$ to detect the captured phospho-NF- $\mathrm{kB}$ p65 protein. After washing with PBS-T, anti-rabbit IgG secondary antibody conjugated with horseradish peroxidase (HRP) was added and incubated for $30 \mathrm{~min}$ at $37^{\circ} \mathrm{C}$. The colour reaction was developed by incubation with $3,3^{\prime}, 5,5^{\prime}$ tetramethylbenzidine (TMB) substrate solution (Cell Signaling, MA, USA). Finally, the reaction was stopped with $0.18 \mathrm{M}$ sulphuric acid. Optical density (OD) was measured at $450 \mathrm{~nm}$. All assays were carried out in duplicate.

\section{Statistical analysis}

Statistical analysis was performed using SPSS version 17.0 software (SPSS, IL, USA). All results were presented 
as mean \pm standard error of the mean (SEM). The normality of distribution was determined by the Kolmogorov-Smirnov test. Differences in levels of urinary sediment NF- $\mathrm{B}$ p 65 between groups were compared by Mann-Whitney U-test. Differences in levels of urinary sediment NF-кB p65 within groups between day 0 and day 7 were tested by Wilcoxon signed-rank test. In addition, the correlation between levels of NF- $\mathrm{kB}$ p65 and pertinent clinical data including age, malaria parasite density, haemoglobin, haematocrit, white blood cells (WBC) and urinary laboratory parameters were calculated using Spearman's rank correlation $\left(r_{s}\right)$. A $p$ value $<0.05$ was considered statistically significant.

\section{Results}

\section{Clinical and laboratory data of malaria patients}

Clinical data of the malaria patients and healthy controls are shown in Table 1 and the results of urinary analysis are presented in Table 2. On admission, the mean malaria parasite density in the group of complicated $P$. falciparum malaria patients without AKI $(\mathrm{Cr}<3 \mathrm{mg} / \mathrm{dl})$ $(670,124$ parasite $/ \mu \mathrm{l})$ was similar to those with AKI $(\mathrm{Cr} \geq 3 \mathrm{mg} / \mathrm{dl})(547,766$ parasite $/ \mu \mathrm{l})(p=0.602)$. At day 7 post-treatment, no asexual form of malaria parasite was found in the peripheral blood of any malaria patient. A significant increase in the level of serum $\mathrm{Cr}$ was found in the group of complicated $P$. falciparum malaria patients with AKI $(6.3 \pm 0.5 \mathrm{mg} / \mathrm{dl})$, compared with complicated $P$. falciparum malaria patients without AKI $(1.8 \pm 0.2 \mathrm{mg} / \mathrm{dl})(p=0.009)$. The Cr level was 3.5 times higher in malaria patients with AKI. No significant difference in serum $\mathrm{Cr}$ was found in $P$. vivax patients $(0.8$ $\pm 0.1 \mathrm{mg} / \mathrm{dl}$ ) and uncomplicated $P$. falciparum patients $(0.9 \pm 0.1 \mathrm{mg} / \mathrm{dl})$, compared with the healthy controls upon admission and day 7 post-treatment (all $p>0.05$ ). Serum BUN was also significantly higher in $P$. falciparum malaria with AKI than in $P$. vivax, uncomplicated $P$. falciparum and $P$. falciparum malaria patients without AKI (all $p<0.05$ ).

All malaria patient groups showed higher proteinuria than the healthy controls upon admission (all $p<0.05$ ). Proteinuria was significantly increased in complicated $P$. falciparum (both with and without AKI groups), compared with $P$. vivax and uncomplicated $P$. falciparum (all $p<0.05$ ) (Table 2). The number of red blood cells $(\mathrm{RBC})$ in the urine was significantly increased in all malaria groups compared with healthy controls upon admission (all $p<0.05$ ). Significantly lower RBC numbers were observed in $P$. vivax and uncomplicated $P$. falciparum, compared with complicated $P$. falciparum (both with and without AKI groups) (all $p<0.05$ ). In addition, the mean number of WBC in the urine sediment was highest in the group of complicated $P$. falciparum malaria with AKI compared with the healthy controls $(p<0.001)$, $P$. vivax, uncomplicated $P$. falciparum and $P$. falciparum malaria patients without AKI (all $p<0.05$ ). At day 7 , the microscopic levels of $\mathrm{RBC}, \mathrm{WBC}$ and epithelial cells remained significantly elevated in the urine samples from complicated $P$. falciparum malaria with AKI patients, compared to the healthy controls $(p=0.02, p=0.001$ and $p<0.001$, respectively) (Table 2 ).

\section{NF-кB p65 level in urinary sediment cells}

NF- $\mathrm{kB}$ p65 levels measured by ELISA in the urinary sediment cells of malaria patients and healthy controls are shown in Figure 1. On admission (day 0), the mean level urinary sediment NF-кB p65 was significantly elevated in complicated $P$. falciparum malaria with AKI $(0.47 \pm 0.02)$, compared with $P$. vivax malaria $(0.21 \pm$ $0.02)$, uncomplicated $P$. falciparum malaria $(0.27 \pm 0.02)$ and complicated $P$. falciparum malaria without AKI (0.36 \pm 0.01$),(p<0.001, p<0.001, p=0.001$, respectively).

Table 1 Demographic data and clinical data of malaria patients and healthy controls

\begin{tabular}{|c|c|c|c|c|c|}
\hline & P. vivax & $\begin{array}{l}\text { P. falciparum } \\
\text { uncomplicated }\end{array}$ & $\begin{array}{l}\text { P. falciparum } \\
\text { complicated } \\
(\mathrm{Cr}<3.0 \mathrm{mg} / \mathrm{dl})\end{array}$ & $\begin{array}{l}\text { P. falciparum } \\
\text { complicated } \\
(\mathrm{Cr} \geq 3.0 \mathrm{mg} / \mathrm{dl})\end{array}$ & Healthy controls \\
\hline$n$ & 11 & 8 & 10 & 10 & 14 \\
\hline Age (year) & $24 \pm 2.6$ & $27 \pm 2.8$ & $27 \pm 1.3$ & $30 \pm 5.9$ & $31 \pm 2.4$ \\
\hline Sex (male:female) & $11: 0$ & $8: 0$ & $5: 0$ & $5: 0$ & $7: 7$ \\
\hline Parasite $(\mu l)$ D0 & $20,376^{a, b}$ & $249,101^{a, b}$ & $670,124^{a}$ & $547,766^{a}$ & 0 \\
\hline Parasite $(\mu \mathrm{l})$ D7 & $0^{c}$ & $0^{c}$ & $0^{c}$ & $0^{c}$ & 0 \\
\hline Serum Cr D0 & $0.8 \pm 0.1^{b}$ & $0.9 \pm 0.1^{b}$ & $1.8 \pm 0.2^{a, b}$ & $6.3 \pm 0.5^{a}$ & $0.8 \pm 0.0$ \\
\hline Serum Cr D7 & $0.8 \pm 0.3^{b}$ & $0.8 \pm 0.6^{b}$ & $0.7 \pm 0.5^{b, c}$ & $8.6 \pm 0.2^{a, c}$ & $0.9 \pm 0.1$ \\
\hline Serum BUN DO & $13.4 \pm 1.0^{b}$ & $15.9 \pm 2.2^{b}$ & $32.6 \pm 4.7^{b}$ & $109.4 \pm 14.0$ & NA \\
\hline Serum BUN D7 & $12.6 \pm 0.8^{b}$ & $12.4 \pm 1.3^{b}$ & $12.8 \pm 0.8^{b, c}$ & $75.6 \pm 0.5^{c}$ & NA \\
\hline
\end{tabular}

${ }^{\mathrm{a}}$ Significance of $p<0.05$ compared with healthy controls.

${ }^{\mathrm{b}}$ Significance of $p<0.05$ compared with $P$. falciparum malaria associated with $\mathrm{AKI}(\mathrm{Cr} \geq 3 \mathrm{mg} / \mathrm{dl})$.

'Significance of $p<0.05$ compared with the day of admission. 
Table 2 Urine analysis of malaria patients and healthy controls

\begin{tabular}{|c|c|c|c|c|c|}
\hline & P. vivax & $\begin{array}{l}\text { P. falciparum } \\
\text { uncomplicated }\end{array}$ & $\begin{array}{l}\text { P. falciparum } \\
\text { complicated } \\
(\mathrm{Cr}<3.0 \mathrm{mg} / \mathrm{dl})\end{array}$ & $\begin{array}{l}\text { P. falciparum } \\
\text { complicated } \\
(\mathrm{Cr} \geq 3.0 \mathrm{mg} / \mathrm{dl})\end{array}$ & Healthy controls \\
\hline$n$ & 11 & 8 & 10 & 10 & 14 \\
\hline Specific gravity D0 & $1.017 \pm 0.0^{\mathrm{a}, \mathrm{b}}$ & $1.017 \pm 0.0^{a}$ & $1.021 \pm 0.0^{\mathrm{a}}$ & $1.021 \pm 0.0^{\mathrm{a}}$ & $1.010 \pm 0.0$ \\
\hline Specific gravity D7 & $1.021 \pm 0.0^{\mathrm{a}}$ & $1.015 \pm 0.0^{b}$ & $1.022 \pm 0.0^{\mathrm{a}}$ & $1.021 \pm 0.0^{a}$ & $1.010 \pm 0.0$ \\
\hline pH D0 & $6.8 \pm 0.3^{b}$ & $6.1 \pm 0.2^{b}$ & $5.6 \pm 0.3^{a, b}$ & $5.0 \pm 0.0^{a}$ & $6.6 \pm 0.2$ \\
\hline pH D7 & $5.6 \pm 0.2^{a, b, c}$ & $6.0 \pm 0.3$ & $6.2 \pm 0.1$ & $6.2 \pm 0.1^{c}$ & $6.3 \pm 0.2$ \\
\hline Urine protein D0 & $27.3 \pm 9.8^{a, b}$ & $43.8 \pm 12.3^{a, b}$ & $62.0 \pm 17^{a}$ & $160.0 \pm 56.7^{\mathrm{a}}$ & $0 \pm 0.0$ \\
\hline Urine protein D7 & $4.5 \pm 3.0$ & $3.1 \pm 3.1^{c}$ & $0 \pm 0.0^{c}$ & $6.0 \pm 4.0^{c}$ & $0 \pm 0.0$ \\
\hline RBC in Urine D0 & $0.7 \pm 0.3^{a, b}$ & $0.5 \pm 0.3^{a, b}$ & $3.4 \pm 1.1^{a}$ & $11.8 \pm 6.4^{a}$ & $0 \pm 0.0$ \\
\hline RBC in Urine D7 & $0.1 \pm 0.1^{b}$ & $0 \pm 0.0^{b}$ & $0 \pm 0.0^{b, c}$ & $6.4 \pm 3.9^{a}$ & $0 \pm 0.0$ \\
\hline WBC in Urine D0 & $0.8 \pm 0.3^{b}$ & $1.6 \pm 0.5^{b}$ & $1.6 \pm 0.2^{a, b}$ & $2.4 \pm 0.2^{a}$ & $1.0 \pm 0.0$ \\
\hline WBC in Urine D7 & $1.1 \pm 0.1^{b}$ & $1.0 \pm 0.0^{b}$ & $2.4 \pm 0.2^{a, b, c}$ & $3.8 \pm 0.3^{a, c}$ & $1.3 \pm 0.2$ \\
\hline Epithelium D0 & $1.1 \pm 0.1^{b}$ & $1.6 \pm 0.3^{b}$ & $1.6 \pm 0.4^{b}$ & $5.0 \pm 1.0^{\mathrm{a}}$ & $1.1 \pm 0.1$ \\
\hline Epithelium D7 & $1.1 \pm 0.1^{b}$ & $1.0 \pm 0.0^{b}$ & $3.0 \pm 0.6^{a, b, c}$ & $10.6 \pm 1.3^{a, c}$ & $1.2 \pm 0.2$ \\
\hline
\end{tabular}

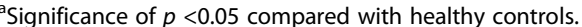

${ }^{\mathrm{b}}$ Significance of $p<0.05$ compared with $P$. falciparum malaria associated with $\mathrm{AKI}(\mathrm{Cr} \geq 3 \mathrm{mg} / \mathrm{dl})$.

'Significance of $p<0.05$ compared with the day of admission.

Compared with the healthy controls $(0.26 \pm 0.01)$, the level of urinary sediment NF- $\mathrm{kB}$ p65 increased significantly in the groups of complicated $P$. falciparum malaria with and without AKI (all $p<0.001$ ). However, $P$. vivax malaria patients showed a significant decrease in urinary sediment NF- $\mathrm{kB}$ p65 level compared with healthy controls $(p=0.019)$, while NF- $\mathrm{KB}$ p65 levels in uncomplicated $P$. falciparum malaria patients were similar to the healthy controls $(p>0.05)$.

On day 7 post-treatment, the NF- $\mathrm{kB}$ p65 levels in the urinary sediment cells were significantly increased in both groups of complicated $P$. falciparum malaria patients (without $\mathrm{AKI}=0.33 \pm 0.02$; with $\mathrm{AKI}=0.48 \pm$
0.02), compared with the healthy controls $(0.25 \pm 0.01$; $p=0.001, p<0.001$, respectively). Among the complicated $P$. falciparum malaria, AKI group showed significantly higher urine NF- $\mathrm{kB}$ p65 levels, compared to those without AKI $(p<0.05)$. In addition, the level of urinary sediment NF- $\mathrm{kB}$ p65 remained significantly decreased in patients infected with $P$. vivax malaria $(0.19 \pm 0.02)$, compared with the healthy controls $(p=$ $0.014)$. The lowest levels of urinary sediment NF- $\mathrm{kB}$ p65 were found in $P$. vivax malaria patients. However, no significant differences in the levels of urine NF- $\mathrm{kB}$ p65 were observed between day 0 and day 7 in all malaria patient groups (all $p>0.05$ ).

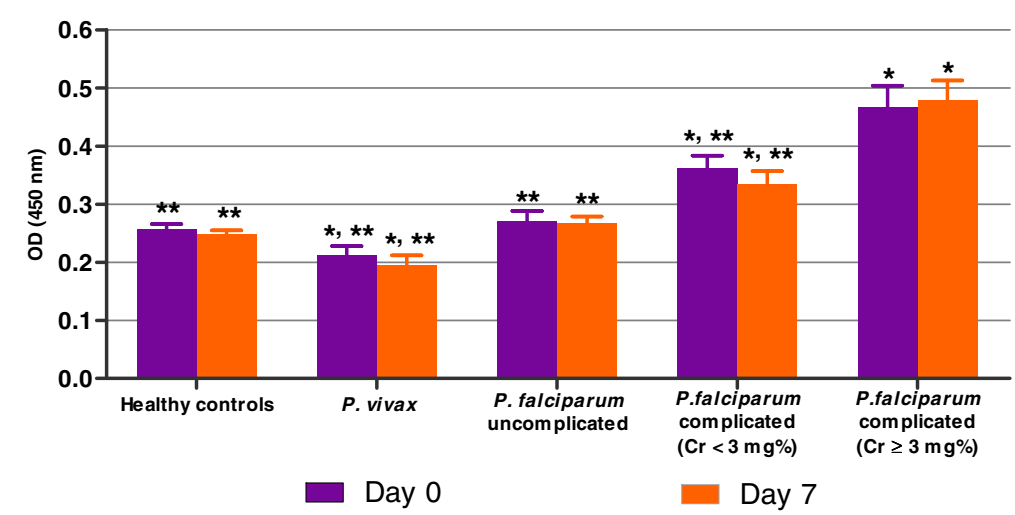

Figure 1 Levels of NF-кB p65 in the urinary sediment cells of malaria patients and healthy controls. Protein isolated from the urinary sediment cells was used to measure the level NF-KB p65 by ELISA. ${ }^{*}$ Significance of $p<0.05$ compared with healthy control. ${ }^{* *}$ Significant of $p<0.05$ compared with $P$. falciparum malaria associated with $\mathrm{AKI}(\mathrm{Cr} \geq 3 \mathrm{mg} / \mathrm{dl})$. 


\section{Correlations between urinary sediment NF-kB p65 level and clinical data}

On admission, NF-kB p65 levels in the urinary sediment cells showed significant positive correlations with serum $\mathrm{Cr}\left(r_{s}=0.792 ; p<0.001\right)$, BUN $\left(r_{s}=0.839 ; p<0.001\right)$, parasite density $\left(r_{s}=0.737 ; p<0.001\right)$ and microscopic $\mathrm{WBC}\left(r_{s}=0.550 ; p<0.001\right)$ (Figure 2$)$. On day 7 posttreatment, NF-kB p65 showed significantly positive correlations with serum $\mathrm{Cr}\left(r_{s}=0.605 ; p<0.001\right)$, BUN $\left(r_{s}=0.596 ; p<0.001\right)$, microscopic WBC $\quad\left(r_{s}=0.820\right.$; $p<0.001)$ and urinary epithelial cells $\left(r_{s}=0.865 ; p<0.001\right)$ (Figure 3).

Within the complicated $P$. falciparum malaria with AKI group, a significant positive correlation was found between NF- $\mathrm{B}$ p 65 in the urinary sediment cells and serum $\mathrm{Cr}$. on the day of admission $\left(r_{s}=0.9000 ; p=0.037\right)$ and on day 7 post-treatment $\left(r_{s}=0.975 ; p<0.005\right)$. There was no significant correlation between NF-k B p65 levels in the urinary sediment cells and other urinary parameters including specific gravity, $\mathrm{pH}$ and urine protein in any malaria patient group.

\section{Discussion}

The precise mechanism of AKI in P. falciparum malaria has not been fully understood. Several hypotheses have been demonstrated including mechanical obstruction by infected PRBCs, immune mediated glomerular pathology, fluid loss due to multiple mechanisms and alterations in renal microcirculation $[4,17,18]$. The histopathological finding in malaria AKI showed a variable mixture of acute tubular necrosis (ATN), interstitial nephritis and glomerulonephritis. ATN is the most consistent histological finding, presenting with cloudy swelling, hemosiderin granular deposits and cell necrosis [4]. An ultrastructural study of the kidney in fatal falciparum malaria showed PRBC sequestration in the glomerular and tubulo-interstitial blood vessels; and acute tubular damage is an important feature [6]. With regard to chemical mediators, inflammatory cells, particularly monocytes stimulated by glycosylphosphatidylinositol, can enhance the synthesis of various cytokine cascades and mediators. These mediators cause changes in blood volume status, vasodilation and increases vascular permeability leading to hypovolaemia which can contribute to ischemic renal failure [17]. Activation of NF- $\mathrm{kB}$ in renal tubular epithelial cells and macrophages in human renal tissues has been reported [14]. In the present study, NF- $\mathrm{kB}$ p65 levels in urinary sediment cells were highest and remained significantly elevated from pretreatment to day 7 post-treatment in complicated $P$. falciparum malaria associated with AKI ( $\mathrm{Cr} \geq 3 \mathrm{mg} / \mathrm{dl})$, compared with healthy controls and other malaria groups. It is possible that activation of NF- $\mathrm{kB}$ p 65 in the urine sediment containing renal epithelial cells and $\mathrm{WBC}$ is triggered by various ligands or proteins of malaria parasites that induce up-regulation of the NF-kB p65 signalling pathway. This eventually leads to nuclear translocation of NF- $\kappa \mathrm{B}$ and regulation of gene expression involved in inflammation and apoptosis. The inflammation in the interstitium of kidney tissue has been proposed to play a major role in the pathophysiology of AKI $[19,20]$. A study also reported that proximal tubular epithelial cells are an important source of cytokine production, such as interleukin (IL)-18 and IL-16. These cytokines enter the interstitium and result in activation of inflammatory cells [21].
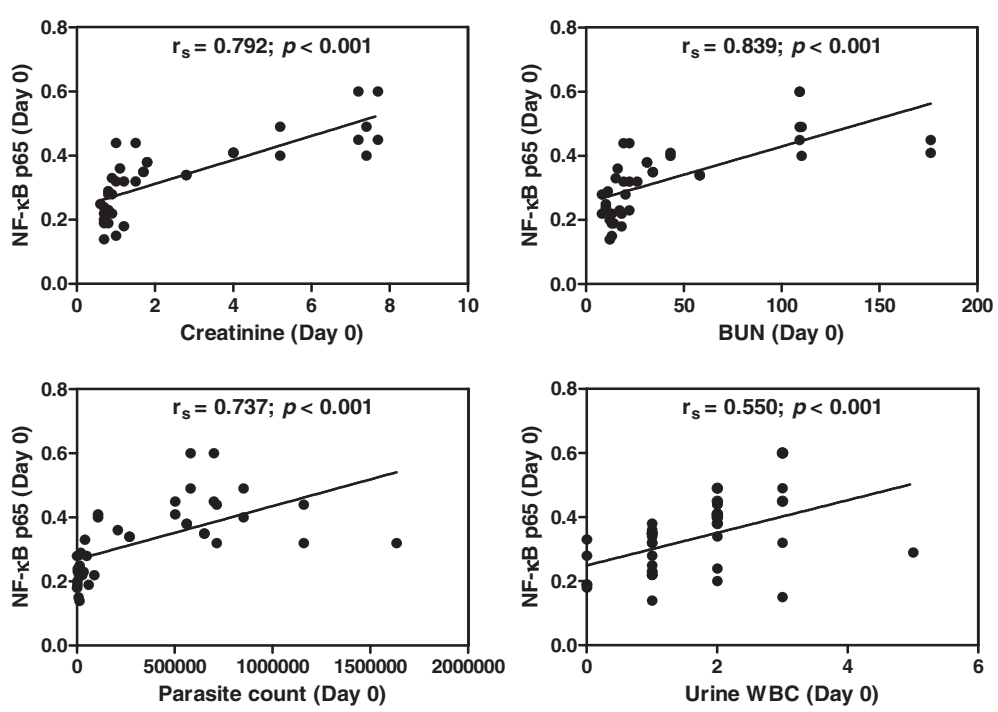

Figure 2 Correlations between urinary sediment NF-KB p65 and clinical data on the day of admission $(\mathbf{n}=39)$. Data analysed by Spearman's rank correlation. 

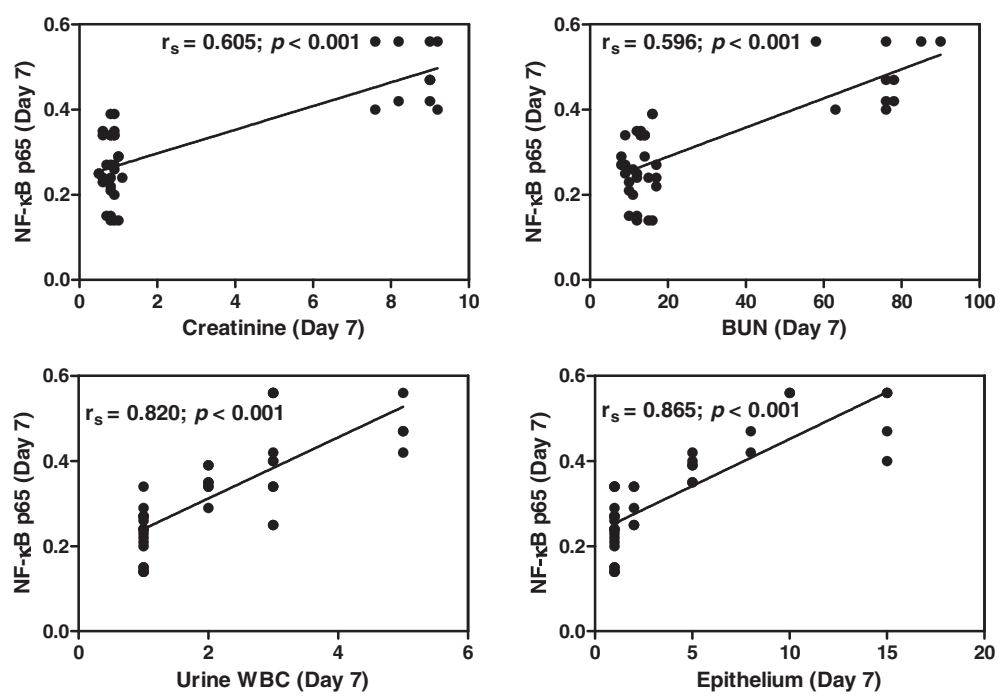

Figure 3 Correlations between urinary sediment NF-KB p65 and clinical data on day 7 post-treatment $(\mathbf{n}=39)$. Data analysed by Spearman's rank correlation coefficient.

In this study, ELISA was used to measure NF-kB p65 levels in urinary sediment cells. Preliminary experiments using urine supernatants from malaria patients were unable to detect NF- $\mathrm{kB}$ p65. Either NF- $\mathrm{kB}$ p65 was not excreted into the urine or the molecule was too diluted within the urine to be measurable directly. Similar finding was documented for urinary haem oxygenese-1 (uHO-1) measurement, where it was undetectable in the urine supernatant [22]. Activation of NF- $\mathrm{kB}$ p65 has been demonstrated in glomeruli, in tubulo-interstitial cells, in infiltrating cells of obstructed kidneys [23], as well as in renal tubular cells [14]. The proximal and distal tubular epithelial cells were documented as major NF-кB p65 producers [22]. Recent studies show that NF- $\mathrm{kB}$ p65 activation has also been detected in peripheral blood mononuclear cells (PBMCs) from complicated P. falciparum malaria patients [24]. The source of NF$\kappa \mathrm{B}$ p65 in urine sediment possibly originated from renal tubular cells, which were detached from the basement membrane into the lumen of renal tubules and/or from the WBC. Both renal epithelial cells and WBC were found upon examination under a light microscope. The NF- $\kappa B$ p65 levels may indicate ongoing renal damage after infection with malaria. Complicated P. falciparum malaria without AKI also showed a rise in NF-kB p65 levels, compared to healthy controls, but was significantly lower than AKI group (Figure 1). Data suggest that NF- $\mathrm{kB}$ p65 levels may reflect the degree of renal tubular damage caused by PRBC sequestration, leading to restricted local blood flow and host cytokine response, contributing to progressive renal tubular injury.

AKI is usually diagnosed by increased serum $\mathrm{Cr}$ or BUN levels. Newer biomarkers have been used for the early diagnosis of AKI, such as IL-18, KIM-1 and NGAL [25]. This study documented a potential role of NF-KB p65 level in urinary sediment cells in assessing AKI in malaria patients. Within the group of complicated $P$. falciparum malaria associated with AKI, a significant positive correlation was found between NF- $\mathrm{kB}$ p65 in the urinary sediment cells and serum $\mathrm{Cr}$ on the day of admission $\left(r_{s}=0.9000 ; p=0.037\right)$ and on day 7 posttreatment $\left(r_{s}=0.975 ; p<0.005\right)$. However, lower urinary NF- $\mathrm{kB}$ p65 levels were detected in P. vivax and uncomplicated $P$. falciparum patients. Therefore, NF-kB p65 may be a valuable indicator of renal cell damage and the subsequent development of AKI in malaria patients. Although, the results show clear statistical significance, a larger sample size and serial determination of urinary NF- $\mathrm{B}$ p 65 levels can further address its benefit over serum $\mathrm{Cr}$ level.

NF- $\mathrm{kB}$ p65 levels in urinary sediment cells showed a significant positive correlation with serum $\mathrm{Cr}$ on the day of admission and day 7 post-treatment. It has been reported that increased serum $\mathrm{Cr}$ was the major factor and an important predictor for mortality among malaria patients with AKI, and that early diagnosis and prompt management including dialysis can reduce mortality [26]. A positive correlation was found between NF- $k B$ p65 levels and parasite density on day of admission. This finding can be associated with a higher risk of developing malaria AKI, as previous study has shown that patients with parasitaemia $>5 \%$, corresponding to 250,000 PRBCs per $\mu \mathrm{l}$ were at higher risk of developing malaria AKI than those with lower parasitaemia [27]. In addition, NF- $\mathrm{KB}$ p65 showed a significant positive correlation with microscopic WBC on day of admission and day 7 
post-treatment. The findings correlate with the activation of NF- $\mathrm{KB}$ p65 reported in the PBMCs of malaria patients [24].

\section{Conclusions}

The levels of NF-kB p65 in urinary sediment cells reflect the degree of damage in renal tubular epithelial cells in malaria patients. Therefore, the urinary level of NF-kB p65 has a potential role as a disease biomarker in estimating damage to renal tubular epithelial cells and subsequent progression of AKI among complicated $P$. falciparum malaria patients. It will be useful to investigate the NF-kB p65 expression level in specific cell types in urinary sediments, to further explore the exact precursor cells of NF-kB and establish its role in the pathogenesis of AKI in malaria.

\section{Competing interests}

The authors declare that they have no competing interests.

\section{Authors' contributions}

CP performed the laboratory work, obtained clinical data and drafted the manuscript. PV designed the experiments, recruited the patients, analysed the data, and revised the final manuscript. Both authors have approved the final version of this manuscript

\section{Acknowledgements}

This study was supported by the Vejdusit Foundation under the Royal Patronage of HRH Princess Galyanivadhana Kromluangnaradhiwasrajanagarindra, founded for the underprivileged Thais. We thank all of the staff at the Department of Tropical Pathology and Hospital for Tropical Diseases, Faculty of Tropical Medicine, Mahidol University, Thailand for their support throughout this study.

\section{Author details}

${ }^{1}$ School of Medicine, Walailak University, 222 Thasala District, Nakhon Si Thammarat 80161, Thailand. ${ }^{2}$ Department of Tropical Pathology, Faculty of Tropical Medicine, Mahidol University, 420/6 Rajvithi Road, Bangkok, Thailand. ${ }^{3}$ Center for Emerging and Neglected Infectious Diseases, Mahidol University, Bangkok, Thailand.

Received: 29 November 2013 Accepted: 2 March 2014 Published: 7 March 2014

\section{References}

1. Dondorp AM, Day NP: The treatment of severe malaria. Trans R Soc Trop Med Hyg 2007, 101:633-634.

2. Prakash J, Singh AK, Kumar NS, Saxena RK: Acute renal failure in Plasmodium vivax malaria. J Assoc Physicians India 2003, 51:265-267.

3. WHO: World Health Organization. Severe falciparum malaria, Communicable Diseases Cluster. Trans R Soc Trop Med Hyg 2000, 94(Suppl 1):S1-S90.

4. Barsoum RS: Malarial acute renal failure. J Am Soc Nephrol 2000, 11:2147-2154.

5. Mishra SK, Das BS: Malaria and acute kidney injury. Semin Nephrol 2008, 28:395-408.

6. Nguansangiam S, Day NP, Hien TT, Mai NT, Chaisri U, Riganti M, Dondorp AM, Lee SJ, Phu NH, Turner GD, White NJ, Ferguson DJ, Pongponratn E: A quantitative ultrastructural study of renal pathology in fatal Plasmodium falciparum malaria. Trop Med Int Health 2007, 12:1037-1050.

7. Schrier RW, Wang W, Poole B, Mitra A: Acute renal failure: definitions, diagnosis, pathogenesis, and therapy. J Clin Invest 2004, 114:5-14.

8. Venkataraman R, Kellum JA: Prevention of acute renal failure. Chest 2007, 131:300-308.

9. Kellum JA: Acute kidney injury. Crit Care Med 2008, 36:S141-S145.
10. Indraprasit S, Sakulsaengprapha A: Acute renal failure (ARF) in Thailand Retrospective analysis in a medical center. J Med Assoc Thai 1997, 80:411-415.

11. Thanachartwet V, Desakorn V, Sahassananda D, Kyaw Win KK, Supaporn T: Acute renal failure in patients with severe falciparum malaria: using the WHO 2006 and RIFLE Criteria. Int J Nephrol 2013, 2013(841518).

12. Mehta RL, Kellum JA, Shah SV, Molitoris BA, Ronco C, Warnock DG, Levin A: Acute Kidney Injury Network: report of an initiative to improve outcomes in acute kidney injury. Crit Care 2007, 11:R31.

13. Nguyen MT, Devarajan P: Biomarkers for the early detection of acute kidney injury. Pediatr Nephrol 2008, 23:2151-2157.

14. Mezzano SA, Barria M, Droguett MA, Burgos ME, Ardiles LG, Flores C, Egido $\mathrm{J}$ : Tubular NF-kappaB and AP-1 activation in human proteinuric renal disease. Kidney Int 2001, 60:1366-1377.

15. Sanz AB, Sanchez-Nino MD, Ramos AM, Moreno JA, Santamaria B, Ruiz-Ortega M, Egido J, Ortiz A: NF-kappaB in renal inflammation. J Am Soc Nephrol 2010, 21:1254-1262.

16. Guijarro C, Egido J: Transcription factor-kappa B (NF-kappa B) and renal disease. Kidney Int 2001, 59:415-424.

17. Eiam-Ong S, Sitprija V: Falciparum malaria and the kidney: a model of inflammation. Am J Kidney Dis 1998, 32:361-375.

18. Sitprija V: Nephropathy in falciparum malaria. Kidney Int 1988, 34:867-877.

19. Bonventre JV, Zuk A: Ischemic acute renal failure: an inflammatory disease? Kidney Int 2004, 66:480-485.

20. Friedewald JJ, Rabb H: Inflammatory cells in ischemic acute renal failure. Kidney Int 2004, 66:486-491.

21. Akcay A, Nguyen Q, Edelstein CL: Mediators of inflammation in acute kidney injury. Mediators Inflamm 2009, 2009:137072.

22. Yokoyama T, Shimizu M, Ohta K, Yuno T, Okajima M, Wada T, Toma T, Koizumi S, Yachie A: Urinary heme oxygenase-1 as a sensitive indicator of tubulointerstitial inflammatory damage in various renal diseases. Am J Nephrol 2011, 33:414-420.

23. Esteban V, Lorenzo O, Ruperez M, Suzuki Y, Mezzano S, Blanco J, Kretzler M, Sugaya T, Egido J, Ruiz-Ortega M: Angiotensin II, via AT1 and AT2 receptors and NF-kappaB pathway, regulates the inflammatory response in unilateral ureteral obstruction. J Am Soc Nephrol 2004, 15:1514-1529.

24. Punsawad C, Krudsood S, Maneerat Y, Chaisri U, Tangpukdee N, Pongponratn E, Nantavisai K, Udomsangpetch R, Viriyavejakul P: Activation of nuclear factor kappa B in peripheral blood mononuclear cells from malaria patients. Malar J 2012, 11:191.

25. Edelstein CL: Biomarkers of acute kidney injury. Adv Chronic Kidney Dis 2008, 15:222-234.

26. Kanodia KV, Shah PR, Vanikar AV, Kasat P, Gumber M, Trivedi HL: Malaria induced acute renal failure: a single center experience. Saudi J Kidney Dis Transpl 2010, 21:1088-1091.

27. Ehrich JH, Eke FU: Malaria-induced renal damage: facts and myths. Pediatr Nephrol 2007, 22:626-637.

doi:10.1186/1475-2875-13-84

Cite this article as: Punsawad and Viriyavejakul: Nuclear factor kappa B in urine sediment: a useful indicator to detect acute kidney injury in Plasmodium falciparum malaria. Malaria Journal 2014 13:84.

\section{Submit your next manuscript to BioMed Central and take full advantage of:}

- Convenient online submission

- Thorough peer review

- No space constraints or color figure charges

- Immediate publication on acceptance

- Inclusion in PubMed, CAS, Scopus and Google Scholar

- Research which is freely available for redistribution 